\title{
The never-ending pursuit of a definitive chemical classification system for granites
}

\author{
Marcos GARCÍA-ARIAS
}

\author{
Departamento de Geociencias, Facultad de Ciencias, Universidad de Los Andes, Carrera 1 \# 18A-2, 110711 Bogotá, \\ m.garcia@uniandes.edu.co
}

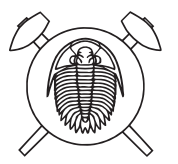

\begin{abstract}
Chemical classifications of granites sensu lato have been developed and revisited over decades, but no classification scheme has been universally accepted yet. The more or less known coupled reasons for this apparently impossible task are reviewed here. The main problem is that different granitoids do not fall in distinct categories with sharp boundaries, but comprise a continuous spectrum of rock types both in their chemical and modal compositions. The unifying factor is the minimum-melt nature of the granites sensu stricto, as primary and evolved melts can have a granitic composition. This minimum-melt nature has two consequences, which are the main reasons for the absence of sharp boundaries in every compositional classification system, either modal or chemical. Firstly, the chemistry of granites spreads from the minimum melt to non-minimum compositions, and thus some granites represent a rock series formed by a continuous magmatic evolution, not by discrete steps; secondly, granite series, which are generated from different sources and by several petrogenetic processes, eventually converge at the most silica-rich compositions. There is a relationship between the tectonic scenarios of formation of granites and the chemical overlap that contributes to the absence of a satisfactory chemical classification: the protracted evolution of the tectonic settings following the Wilson cycle and more complicated scenarios change the chemical and modal composition of the granite sources. The overlap in the most silica-rich compositions of the granites s.l. due to the minimum melt nature may extend to more mafic members in a granite series: the closer the sources are in their composition, the greater is the overlap, becoming a second contribution to the lack of sharp boundaries between granite types.

The huge efforts to create a satisfactory chemical compositional classification system have actually led to a significant contribution to granite petrology: the discovery of the main chemical differences between granite types, the main chemical parameters (silica content, alkalinity, aluminosity, maficity or $\mathrm{FeOt}+\mathrm{MgO}$ content, and the $\mathrm{Fe} / \mathrm{Mg}$ and $\mathrm{Na} / \mathrm{K}$ ratios) and the petrogenetic processes that cause the change in these parameters. Therefore, despite the lack of agreement over the 'perfect' classification system, the investigations have not been fruitless: they have led to the realization that non-genetic classifications are preferable to name the individual rock samples; chemical classification schemes should be left to distinguish magmatic suites and to unravel their prospective petrogenesis and geotectonic setting.
\end{abstract}

Keywords: granites, chemical classifications, tectonic settings, magmatic evolution, petrogenesis

Received: 14 May 2020; accepted: 29 September 2020; handling editor: V. Janoušek

The online version of this article (doi: 10.3190/jgeosci. 313) contains supplementary electronic material.

\section{Introduction}

Granites sensu stricto are plutonic, silica-rich and felsic rocks that fall in the field 3 of the QAPF diagram of Streckeisen (1976), i.e., rocks that contain modal quartz (Q), alkali feldspar (A) and plagioclase (P) in the following proportions: $20<\mathrm{Q}<60$ and $\mathrm{A}: \mathrm{P}=90: 10$ to $35: 65$. If other granitoids are included, then granites sensu lato are plutonic rocks with $20<\mathrm{Q}<60$ (Le Maitre 2002). This definition of granites has a main advantage but, at the same time, a main disadvantage. The advantage is that there is no need to determine which other minerals are present in the rock nor how these rocks formed, i.e., there is no genetic implication in that definition. Therefore, it is a straightforward way to identify granites in the field, hand samples and thin sections (unless the rock is too fine-grained to recognize the minerals or too coarse-grained to obtain trustworthy mineral proportions by point counting). The disadvantage is that granites s.l. contain more minerals than quartz and feldspars, and this non-QAP mineral fraction is variable both in nature (e.g. garnet, muscovite, Al-rich/Al-poor biotite, metaluminous to alkaline amphibole or pyroxenes, plus various accessory phases) and amount (up to 40 vol. \%). The presence and modal contents of these other minerals contain information on the chemical composition of the source, melting conditions and petrogenetic processes that produced the granitoids, information that is lost in the QAP definition (e.g. Glazner et al. 2019).

Consequently, several other classification systems for granitoids have been developed over time (see Bonin et al. 2020 for a recent review). Some of these schemes were developed to find a relationship between the chemistry of granitoids and their prospective sources, like the 
alphabetic classification (Chappell and White 1974, 2001; Loiselle and Wones 1979; White 1979), or between the granitoids and their tectonic setting of formation (e.g. Pearce et al. 1984). Some others relied on chemical variations between granite samples or between granite series, like the ASI, modified alkali-lime index (MALI), Fe-number and alkalinity index vs. $\mathrm{SiO}_{2}$ diagrams of Frost et al. (2001) and Frost and Frost (2008). Finally, some attempts to couple mineralogical, petrographic and geochemical information have also been made (Barbarin 1990, 1999; Patiño Douce 1999). Yet, despite these continuous efforts to find a satisfactory classification system, new studies question (e.g. Glazner et al. 2019) or reformulate (e.g. Frost et al. 2016; Bonin et al. 2020) previous schemes.

The aim of this paper is not to provide a thorough review of all the classification systems of granitoids (for this, the reader is referred to Bonin et al. 2020) but to review the more or less known reasons why a definitive classification system based on the granite chemistry seems to be impossible to develop, and what consequences it has for the utility of classification systems of granites s.l. This manuscript will focus on major elements, but the conclusions could also be applied to classifications based on trace elements and isotopes. For the remainder of this manuscript, the terms "granite" and "granitoid" will be used interchangeably with the meaning of "granites s.l.", unless specified.

\section{2. 'Imperfect' chemical classification systems}

A satisfactory classification system of granitoids and related rocks based on chemical variables has been sought for decades because, since the establishment of the S/I typology of Chappell and White $(1974,2001)$, it was realized that the major, trace and/or isotopic composition of granites reflects both the nature of their sources and the processes that the magmas underwent until their eventual crystallization (e.g. Rollinson 1993; Winter 2001). In other words, the chemistry of the granitoids and associated mafic rocks carries information on their genesis. Therefore, many classification systems moved from only giving a name to a sample based on its modal mineralogy, chemical composition and/or texture to tell how it formed. However, the large number of proposed classifications clearly shows that no system is fully satisfactory.

The 'perfect' rock classification system should yield names that convey all the relevant information about the given sample: modal mineralogy, texture, chemical composition and genesis. However, any classification system requires discrete categories significantly distinct to easily establish their boundaries. This may be the case for biological classifications, where an animal either gives birth or lay eggs, with no cases in between, but this is not the case of rocks, which show continuous variations in their modal and chemical composition. Therefore, any rock classification system is necessarily hampered by the need to draw somewhat arbitrary divisions to create pigeonholes in which to classify the samples, divisions that require the agreement of the majority of the scientific community. This is the case of the modal classification system of plutonic rocks of Streckeisen (1976) and the two editions of the recommendations of the IUGS Subcommission on the Systematics of Igneous Rocks (Le Bas and Streckeisen 1991; Le Maitre 2002), although a debate on this classification is still ongoing (e.g. Glazner et al. 2019).

\section{The reasons of this 'imperfection'}

The main factor that causes that no chemical classification of granites is universally accepted is that granites s.s. represent the minimum melts of any silica-saturated and oversaturated silicate system. Therefore, they correspond to either primary melts produced by partial melting of felsic to mafic sources or to evolved melts resulting from fractional crystallization of mafic-intermediate parental magmas (Fig. 1). This fact has two important consequences that are the main reasons for the failure to find a 'perfect' classification system. Firstly, the chemistry of granites spreads from the minimum melt to non-minimum compositions in a continuous and gradual way rather than in discrete steps, causing a lack of sharp differences in the chemical and modal compositions of the rocks, with no pigeonholes. Secondly, the chemistry of melts with different origins and evolutionary paths (and thus representing different types) will eventually overlap when reaching the minimum melt composition (Fig. 1), making the identification of these types virtually impossible. For instance, Bonin et al. (2020) found that about a quarter of the granites in their database, comprising plutons of different ages, types, regions and tectonic settings, have a restricted subaluminous to mildly peraluminous composition with $\mathrm{SiO}_{2} \geq 70$ wt. $\%$ and $\mathrm{K}_{2} \mathrm{O} \sim 4-5$ wt. \%.

Regarding the first reason, there are several magmatic processes that produce melts or magmas of non-minimum chemistry: fractional crystallization, crystal accumulation, restite entrainment, assimilation of country rocks, magma mixing, and others. A thorough treatment of these processes is not the scope of this manuscript, and the reader is referred to Clemens and Stevens (2012) for this discussion. In any case, what is interesting about these processes is that each one modifies the chemistry of the 
parental melt or magma in a different direction. Fractional crystallization, arguably the most important process in producing chemical variation of magmas, causes mafic melts to become more felsic (e.g. Ulmer et al. 2018). Restite entrainment results in the reverse: felsic melts become more mafic magmas (White and Chappell 1977; Stevens et al. 2007; García-Arias and Stevens 2017). Formation of cumulates as a consequence of fractional crystallization or melt extraction from crystal-rich magma reservoirs also produce trends to generally less siliceous compositions, either more mafic or feldspar-rich (e.g. Gelman et al. 2014). Magma mixing or assimilation of country rocks cause a dual change in the chemical and modal composition of both endmembers (generally felsic and mafic, respectively) to intermediate hybrid magmas (e.g. García-Moreno et al. 2006; Díaz-Alvarado et al. 2011). As a consequence of this variety of processes, the mafic compositions of a rock series may represent either the least evolved or an evolved stage in a magma differentiation series, depending on the process responsible.

Many of these processes make the source chemistry of an igneous series to be closer to the most mafic/ less siliceous end-member of this series. For instance, fractional crystallization of a primary basaltic melt can produce an igneous series up to granitic compositions, and the most mafic samples of this series (the parental magmas) are the closest in composition to the source. In the case of restite entrainment, mass-balance restrictions make the source rock of a melt to lie compositionally between the siliceous melt and the mafic mineral residuum; consequently, the increase in maficity of the magma due to restite entrainment moves the magma chemistry closer to the source. This relation between granite and source

Fig. 1 The modal QAP diagram of Streckeisen (1976) showing the fields of primary melts or magmas (shaded and numbered areas) and their evolutionary paths (dashed lines). Area 1 represents primary granitic magmas, whilst areas 2 to 5 are occupied by non-granitic magmas that evolve toward a granitic composition by fractional crystallization. 1: granitic and alkali-feldspar granitic melts; 2: tonalitic and trondhjemitic melts; 3 : monzonitic and quartz monzonitic melts; 4: andesitic and basaltic andesitic melts; 5: tholeiitic basaltic melts. Simplified from figure 6.12 of Castro (2015) except for the extension of area 1 toward the granitic s.s. field. For the naming of each specific field of the QAP diagram, the reader is referred to Le Maitre (2002). chemistry, well known since the seminal work of Chappell and White (1974 and subsequent papers), is probably best showcased in the B-A diagram of Debon and Le Fort $(1983,1988)$ modified by Villaseca et al. (1998) (Fig. 2a). Still, some other projections like the A/CNK vs. A/NK plot of Shand (1943) (Fig. 2b), the $\mathrm{SiO}_{2}-\mathrm{MALI}$ (modified alkali-lime index) diagram of Frost et al. (2001) (Fig. 2c) or the $\mathrm{SiO}_{2}-\mathrm{Fe}^{*}$ plot of Frost et al. (2001) (Fig. 2d) also show this relation. Consequently, the most mafic varieties in an igneous series typically give the most accurate information about the chemistry of the source.

This is the case of the Cordierite-bearing Peraluminous Granitoids (CPG) and Muscovite-bearing Peraluminous Granitoids (MPG), which require a metasedimentary source, and of the Amphibole-bearing Calc-alkaline Granitoids (ACG), Arc Tholeiitic Granites (ATG) and Peralkaline and Alkaline Granites (PAG), which point to a mantle-crust hybrid source (granitoid nomenclature after Barbarin 1996, 1999 and Bonin et al. 2020). The B-A diagram (Fig. 2a) also illustrates the causes of the second reason for the lack of a satisfactory chemical classification system, the overlap between granite series. All series converge at the most silica-rich compositions due to the minimum nature of the granitic melts mentioned above. The closer the sources are in their chemical compositions, the greater is the overlap (see e.g. the ACG + ATG vs. the PAG in Fig. 2a). Only when the sources have contrasting chemistries (like the CPG + MPG vs. the PAG) do

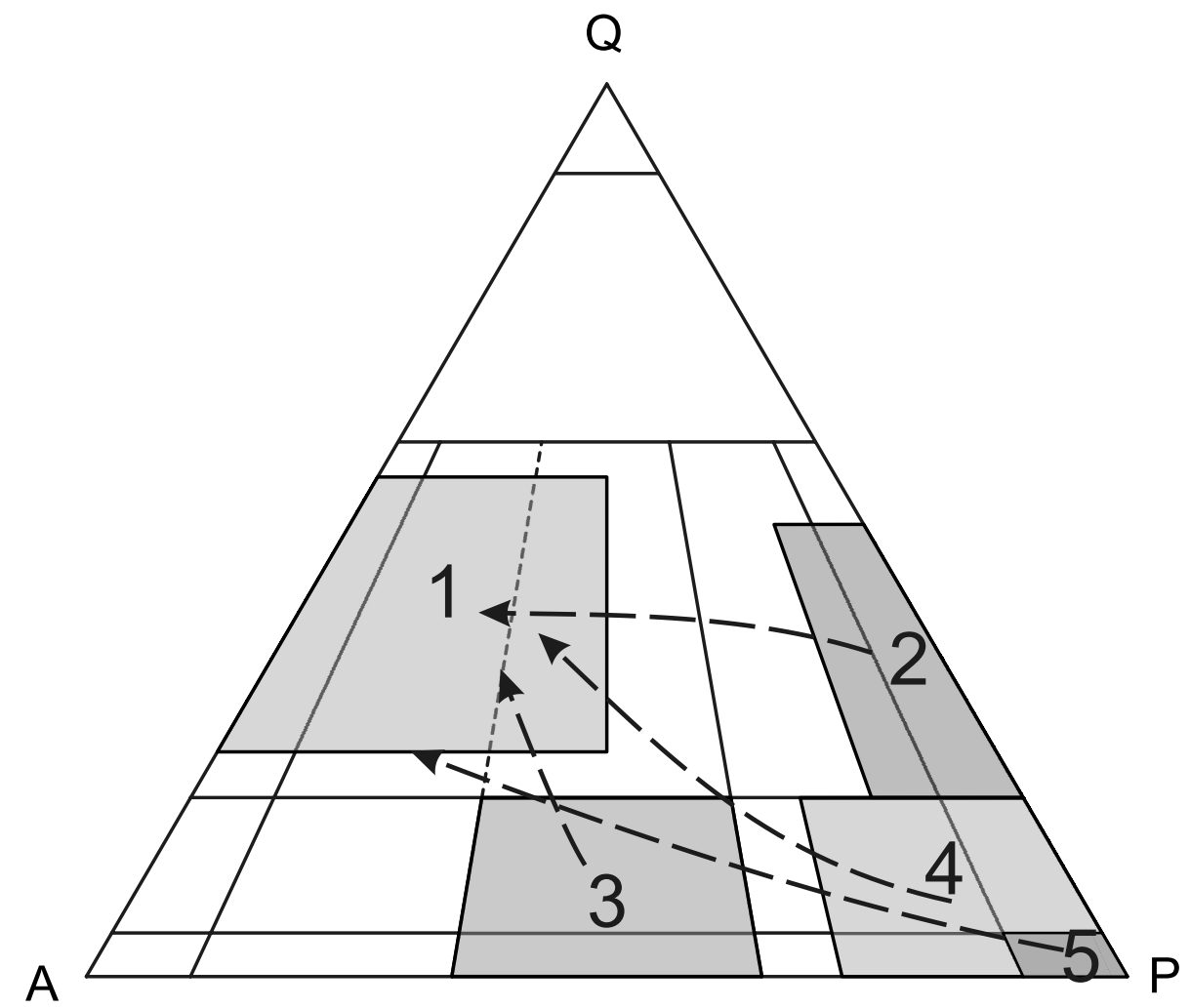


the granites have also significantly different compositions and overlap will only occur at the most silica-rich varieties. A corollary of the source-granite relationship is that granite series differ the most in their most mafic varieties and thus these mafic varieties are the ones that are suited best to distinguish between granite series, as previously stated by e.g. Chappell and White (1992). Another conclusion that can be drawn is that, when two granite groups point to the same source but not exactly along the same direction (like the ACG + ATG and the
PAG, Fig. 2), the magmas likely originated at different $\mathrm{P}-\mathrm{T}$ conditions and differentiated by dissimilar magmatic processes.

Another interesting aspect regarding the granitesource connection and its relation with classification systems is that chemical and modal compositions of granites are indirectly linked to the tectonic setting in which they form (e.g. Pearce 1996). The link is the composition of the source: tectonic settings control the chemical and modal compositions of the granite sources, and the
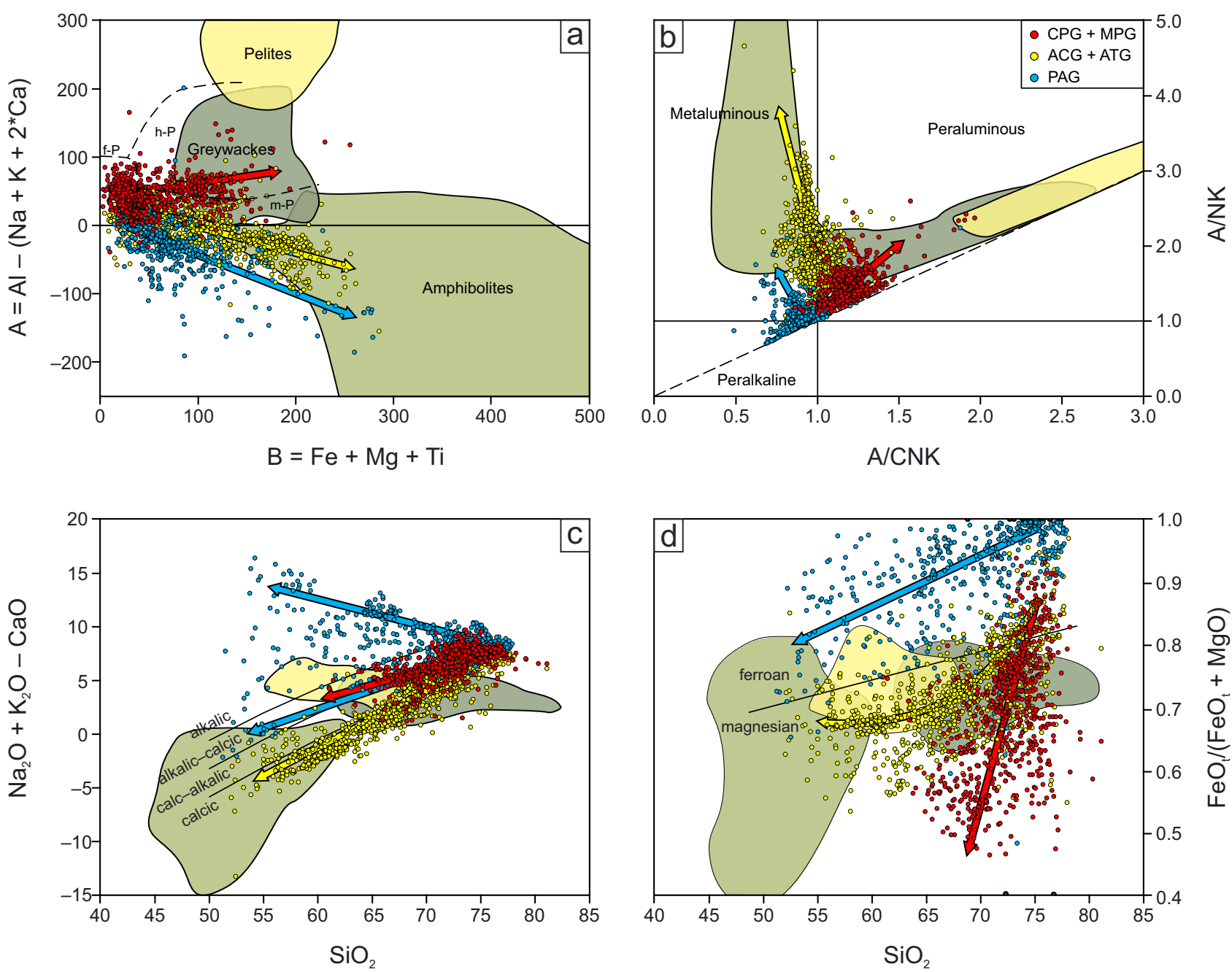

Fig. 2 Compositional differences and overlaps between several granitoid types, and their relation with source composition. Granitoid analyses selected for the plot are the Cordierite-bearing Peraluminous Granitoids and Muscovite-bearing Peraluminous Granitoids (CPG + MPG), Amphibole-bearing Calc-alkaline Granitoids and Arc "Tholeiitic" Granitoids (ACG + ATG) and Peralkaline and Alkaline Granitoids (PAG) (data from collection of Bonin et al. 2020). This collection contains samples mainly from: CPG and MPG - the Lachlan Fold Belt of Australia, the European Variscan Belt and the Cape Fold Belt of South Africa; ACG + ATG - the Lachlan Fold Belt of Australia, Japan, the Aleutian Islands and western North and South America; PAG - original database of Eby (1992) supplemented by analyses of Deccan, Etendeka and the North Atlantic Igneous Province large igneous provinces and the Eastern African rift. The K-rich Calc-alkaline Granitoids (KCG) and the tonalites-trondhjemites-granodiorites (TTG) are not included for simplicity. The datasets defining the composition of the pelitic, greywackic and amphibolitic sources and their references are given in Electronic supplementary material (ESM 1). The diagrams used are the multicationic B-A diagram of Debon and Le Fort $(1983,1988)$ modified by Villaseca et al. (1998) (a), the A/CNK vs. A/NK diagram of Shand (1943) (b), the SiO - -MALI (modified alkali-lime index) diagram of Frost et al. (2001) (c) and the $\mathrm{SiO}_{2}-\mathrm{Fe}^{*}$ diagram of Frost et al. (2001) modified by Frost and Frost (2008) (d). The arrows point to the main sources of each granite type; in the case of the PAG in the $\mathrm{SiO}_{2}-\mathrm{MALI}$ diagram, these granites show a wide fan of evolutionary trajectories and the blue arrows mark the limits of this fan. In general, the more silica-rich the granites are, the higher the degree of the overlap is. 
sources control the composition of the granites. Not all sources are present in all tectonic scenarios or, at least, in similar proportions: thus, specific sources tend to appear in specific scenarios. For instance, metasedimentary sources are more likely to be found in collisional zones (crustal thickening processes), and mantle with very minor to no sedimentary input is more likely involved in ocean ridges and intra-oceanic hot-spots. Tectonic settings are not stable, but evolve continuously during the Wilson cycle. Therefore, sources also undergo a continuous and gradual variation in their chemistry and modal mineralogy; consequently, the protracted evolution of these tectonic scenarios is another reason for the overlap between granite series and thus for the absence of a satisfactory chemical classification system. Following the Wilson cycle and the nomenclature of Barbarin (1999) and Bonin et al. (2020) for granite types, the magmas in recently-formed island-arc settings have a tholeiitic basaltic chemistry and the minor granites and associated mafic rocks formed (gabbro to tonalite plutonic bodies, the ATG) would inherit such a character. Island arcs can evolve to a thicker and more 'continental' subduction setting and the magmas become more silica-rich (and granitic). This reflects the increasing participation of continental material in the production of the magmas via assimilation of lower crustal rocks, subducted sediments or melting of the underplated mafic lower crust (see Castro 2014 for a review of these processes). These new granites would be the ACG. The closure of the ocean triggered by the subduction brings together the accretionary prism, made of mainly metagreywackes, and the pelitic continental platform and slope of the arriving continents, eventually ending the subduction in a continental collision. This process increases the continental component of the source and reduces the mantellic one, thus causing a transition of the granite source to a silica- and Al-richer chemical composition, and granites to transition from pre-collisional ACG to the syn- to post-collisional CPG and MPG. The post-collisional to post-orogenic stage causes thinning of the thickened continental crust, with asthenospheric rise and often some mantle input, leading to the formation of K-rich Calc-alkaline Granitoids (KCG). Further thinning and likely increased mantle input leads to continental rifting and the formation of PAG. Continental material that may contribute to the $\mathrm{KCG}$ and PAG granites may include some of the CPG, MPG and/or ACG present in the thinning crust, and thus a transition from $\mathrm{CPG} / \mathrm{MPG}$ and/or ACG to KCG and/or PAG may be possible. If the rifting proceeds further to open a full ocean, these PAG may eventually be replaced by Ridge Tholeiitic Granites (RTG) in oceanic ridges, and these latter granites may transition to ATG and ACG if subduction begins again, completing the cycle (see table 18-4 of Winter 2001). More complex scenarios, like flat-slab subduction or subduction roll-back, back-arc spreading, asthenosphere-continental lithosphere interaction in rifting continents, asthenospheric ascent due to the break-off of subducting slabs or mantellic input in continents due to delamination of the lower crust, may lead to further modifications of the sources and thus other gradational transitions from one type of granite to another. The tonalites-trondhjemites-granodiorites (TTG) do not fall in this geotectonic classification and thus represent another different category.

\section{The paradox of the chemical classifications}

No matter which criteria are used to divide granitoids in groups and to define the boundaries in classification systems, the continuous gradation in the chemical and modal composition of the granitoids within a granite series and the overlap between series due to the processes described above leads to a spread of granitoids beyond those boundaries (e.g. Frost et al. 2001; Glazner et al. 2019). In my personal opinion, these reasons should be enough to discard a chemical criterion to name granites s.l., as no pigeonhole typologies with significant differences can be established. In fact, some authors have even proposed to include all felsic granites in a single category irrespective of their origin (the felsic peraluminous (leuco-) granitoids of Villaseca et al. 1998; the peraluminous leucogranites of Frost et al. 2001, 2016, and the leucogranites of Frost and Frost 2008). However, new evaluations of the existing classification schemes (e.g. Frost et al. 2016; Bonin et al. 2020; this manuscript) are being constantly produced. Therefore, the question is: why do we keep establishing more classifications or revising them?

The answer to this question can be deduced from a comment by Janoušek and Moyen (2020): "whole-rock geochemistry represents a powerful tool in deciphering petrogenesis of magmatic suites, including granitoids, that can be used to formulate and test hypotheses qualitatively and often also quantitatively. Typically, it can rule out impossible/improbable scenarios and further constrain the process inferred on geological and petrological grounds". In other words, we keep producing more classifications or evaluating the already established ones because, in doing so, we aim to better understand the causes and processes that led to the chemical composition, modal mineralogy and petrogenesis of the granites. The efforts to find the main divisions between granite categories led to the discovery of the key chemical parameters changing during source generation, magma production and subsequent differentiation (silica content, alkalinity, aluminosity, maficity or FeOt $+\mathrm{MgO}$ content and the $\mathrm{Fe} / \mathrm{Mg}$ and $\mathrm{Na} / \mathrm{K}$ ratios, Frost et al. 2001; Frost and Frost 2008; Bonin et al. 2020), and thus 
to an understanding of the processes responsible for these changes. Therefore, the goal of the chemical classification systems of the granitoids has gradually shifted from giving a name to a rock sample to also understand the genesis of associated rock suites (e.g. plutonic units). In my opinion, the task of naming rocks should therefore be left on the non-genetic classifications (e.g. Streckeisen 1976 and Le Maitre 2002), while the chemical schemes provide complementary insights to their genesis and geodynamic setting.

This is an interesting shift from the original purpose of any classification system, to put a name to an item. Consequently, a chemical classification of granite rocks, rather than just typifying a rock in a single category, should also highlight the relationships between the key compositional variables of the granitoids and their origin, their tectonic context and the evolution of the Earth's crust and mantle. Unravelling these relationships has become as important as naming a rock. In my opinion, the goal of studying a granitic rock based on its chemistry should be its petrogenetic interpretation, not its labelling or 'typification' in a category (Miller et al. 2020). A corollary of this conclusion, given the differences in granite series with increasing maficity, is that studying the more mafic compositions of a rock series is a good way to classify the felsic rocks of the same series. The degree of overlap between series also provides information on how close the compositions of the sources were to each other, and thus it can theoretically provide information on the tectonic scenario in which those sources formed. Comparing the tectonic scenario of formation of the sources with the scenario in which the granites appear, coupled with geochronological dating, can constrain the source-to-granite geotectonic evolution of the region (e.g. Fiannacca et al. 2019). Finally, different granite series originated from the same sources but following distinct compositional paths imply different petrogenetic processes in the evolution of the magmas.

\section{Conclusions}

The never-ending pursuit of a satisfactory classification system of granitoids has substantially contributed to an improved understanding of the processes that change the composition of their parental magmas and the source-togranite and tectonic scenario-to-granite relations. Nongenetic modal classifications are preferable to name the individual rock samples; chemical classification schemes should be used to subdivide the granitoid suites, to unravel their petrogenesis and to better understand the granite-source-tectonic setting relation.

Acknowledgements. I am indebted to J. A. Dahlquist for reviewing a previous version of this manuscript, M. P.
Silva for her help in creating Fig. 2, and the reviewers P. Fiannacca, C. Miller and C. Villaseca for their thorough and helpful comments. V. Janoušek is thanked for his editorial handling. The opinions expressed in this manuscript are personal and do not necessarily reflect those of the reviewers. This work was funded by internal funds of the University of Los Andes (FAPA - Fondo de Ayuda a Profesores Asistentes), FAPA number INV2019-63-1701.

Electronic supplementary material. Supplementary table of the chemical analyses of pelites, greywackes and amphibolites used in Fig. 2 is available online at the Journal web site (http://dx.doi.org/10.3190/jgeosci.313).

\section{References}

BARBARIN B (1990) Granitoids: main petrogenetic classifications in relation to origin and tectonic setting. Geol J 25: 227-238

BARBARIN B (1996) Genesis of the two main types of peraluminous granitoids. Geology 24: 295-298

BARBARIN B (1999) A review of the relationships between granitoid types, their origins and their geodynamic environments. Lithos 46: 605-626

BONIN B, JANOUŠEK V, MOYEN J-F (2020) Chemical variation, modal composition and classification of granitoids. In: JANOUŠEK V, BONIN B, COLlins WJ, FARINA F, BOWDEN P (eds) Post-Archean Granitic Rocks: Contrasting Petrogenetic Processes and Tectonic Environments. Geological Society of London Special Publications 491: 9-51

CASTRO A (2014) The off-crust origin of granite batholiths. Geosci Front 5: 63-75

CASTRo A (2015) Petrografía de Rocas Ígneas y Metamórficas. Paraninfo, Madrid, pp 1-260

Chappell BW, White AJR (1974) Two contrasting granite types. Pacific Geol 8: 173-174

Chappell BW, White AJR (1992) I- and S-type granites in the Lachlan Fold Belt. Trans Roy Soc Edinb, Earth Sci 83: 1-26

Chappell BW, White AJR (2001) Two contrasting granite types: 25 years later. Aust J Earth Sci 48: 489-499

Clemens JD, Stevens G (2012) What controls chemical variation in granitic magmas? Lithos 134-135: 317-329

DeBOn F, Le Fort P (1983) A chemical-mineralogical classification of common plutonic rocks and associations. Trans Roy Soc Edinb, Earth Sci 73: 135-149

Debon F, Le Fort P (1988) A cationic classification of common plutonic rocks and their magmatic associations: principles, method, applications. Bull Minéral 111: 493-510

Díaz-Alvarado J, Castro A, Fernández C, MorenoVentas I (2011) Assessing bulk assimilation in cordier- 
ite-bearing granitoids from the Central System Batholith, Spain; experimental, geochemical and geochronological constraints. J Petrol 52: 223-256

EBY GN (1992) Chemical subdivision of the A-type granitoids: petrogenetic and tectonic implications. Geology 20: 641-644

Fiannacca P, Williams IS, Cirrincione R, Pezzino A (2019) Poly-orogenic melting of metasedimentary crust from a granite geochemistry and inherited zircon perspective (southern Calabria-Peloritani Orogen, Italy). Front Earth Sci 7: 119

Frost BR, Frost CD (2008) A geochemical classification for feldspathic igneous rocks. J Petrol 49: 1955-1969

Frost BR, Barnes CG, Collins WJ, Arculus RJ, Ellis DJ, Frost CD (2001) A geochemical classification for granitic rocks. J Petrol 42: 2033-2048

Frost CD, Frost BR, Beard JS (2016) On silica-rich granitoids and their eruptive equivalents. Amer Miner 101: 1268-1284

García-Arias M, Stevens G (2017) Phase equilibrium modelling of granite magma petrogenesis: A. An evaluation of the magma compositions produced by crystal entrainment in the source. Lithos 277: 131-153

García-Moreno O, Castro A, Corretgé LG, El-Hmidi $\mathrm{H}$ (2006) Dissolution of tonalitic enclaves in ascending hydrous granitic magmas: an experimental study. Lithos 89: 245-258

Gelman SE, Deering CD, Bachmann O, Huber C, GUTIÉRREZ FJ (2014) Identifying the crystal graveyards remaining after large silicic eruptions. Earth Planet Sci Lett 403: 299-306

Glazner AF, Bartley JM, Coleman DS (2019) A more informative way to name plutonic rocks. GSA Today $29,4-10$

JANOUŠEK V, MOYEN J-F (2020) Whole-rock geochemical modelling of granite genesis - the current state of the play. In: JANOUŠEK V, Bonin B, COLlins WJ, FARINA F, BowdEN P (eds) Post-Archaean Granitic Rocks: Contrasting Petrogenetic Processes and Tectonic Environments. Geological Society of London Special Publications 491: 267-291

Le Bas MJ, Streckeisen A (1991) The IUGS systematics of igneous rocks. J Geol Soc, London 148: 825-833

LE MAITRE RW (ed.) (2002) Igneous Rocks: a Classification and Glossary of Terms: Recommendations of the International Union of Geological Sciences, Subcommission on the Systematics of Igneous Rocks, $2^{\text {nd }}$ Ed. Cambridge University Press, Cambridge, pp 1-236

LoISELlE MC, Wones DS (1979) Characteristics and origin of anorogenic granites. Geological Society of America, Abstracts with Programs 11: 468

Miller CF, Miller JS, Gualda GAR (2020) Felsic magma diversity \& triumphs and perils of granite typology. Goldschmidt 2020 Conference Abstracts: 1804

Patiño Douce AE (1999) What do experiments tell us about the relative contribution of crust and mantle to the origin of granitic magmas? In: CASTRO A, FERnÁndez C, VIGNERESSE JL (eds) Understanding Granites: Integrating New and Classical Techniques. Geological Society of London Special Publications 168: 55-76

PEARCE JA (1996) Sources and settings of granitic rocks. Episodes 19: 120-125

PeArce JA, Harris NBW, Tindle AG (1984) Trace element discrimination diagrams for the tectonic interpretation of granitic rocks. J Petrol 25: 956-983

Rollinson HR (1993) Using Geochemical Data: Evaluation, Presentation, Interpretation, $1^{\text {st }}$ Ed. Longman, London, pp 1-352

Shand SJ (1943) The Eruptive Rocks, $2^{\text {nd }}$ Ed. John Wiley, New York, pp 1-444

Stevens G, Villaros A, Moyen J-F (2007) Selective peritectic garnet entrainment as the origin of chemical diversity in S-type granites. Geology 35: 9-12

StreCKeISEN A (1976) To each plutonic rock its proper name. Earth Sci Rev 12: 1-33

Ulmer P, KAEGi R, Müntener O (2018) Experimentally derived intermediate to silica-rich arc magmas by fractional and equilibrium crystallization at $1.0 \mathrm{GPa}$ : an evaluation of phase relationships, compositions, liquid lines of descent and oxygen fugacity. J Petrol 59: $11-58$

Villaseca C, Barbero L, Herreros V (1998) A re-examination of the typology of peraluminous granite types in intracontinental orogenic belts. Trans Roy Soc Edinb, Earth Sci 89: 113-119

WHITE AJR (1979) Sources of granite magmas. Geological Society of America, Abstracts with Programs 11: 539

White AJR, CHAPPELl BW (1977) Ultrametamorphism and granitoid genesis. Tectonophysics 43: 7-22

WinTER JD (2001) An Introduction to Igneous and Metamorphic Petrology. Prentice Hall, New Jersey, pp 1-697 